\title{
Pengaruh Manajemen Mutu terhadap Kompetensi Pedagogik Guru di SMP Unggulan Mukhtar Syafa'at Blokagung Banyuwangi
}

\author{
Mahbub $^{1}$, Bambang Sugiarto ${ }^{2}$ \\ e-mail: mahbubnawawi08@ gmail.com¹, afhishaidar@gmail.com² \\ Program Studi Manajemen Pendidikan Islam \\ Institut Agama Islam Darussalam Blokagung Banyuwangi
}

\begin{abstract}
The objectives of this study are 1). to find out mutuyang management in SMP Unggulan Mukhtar Syafa'at Blokagung Banyuwangi, 2). to find out the pedagogical competence of teachers in SMP Unggulan Mukhtar Syafa'at Blokagung Banyuwangi, 3). to determine the effect of quality management on the pedagogical competence of teachers in SMP Unggulan Mukhtar Syafa'at Blokagung Banyuwangi. This research used quantitative descriptive method with product moment technique in data validity test and to find data reliability using alpha formula, while in hypothesis testing using $F$ test and $T$ test then for data analysis technique using normality test using regression model. Based on the results of research that has been done, the quality management managed by the institution can be said to be good. The pedagogical competence of the teachers at Mukhtar Syaudang Superior Junior High School was classified as good with a score percentage of $61 \%-80 \%$, meaning that the teacher's pedagogical competence was good. Then quality management greatly affects the pedagogical competence of teachers, which is $70.2 \%$ and $29.8 \%$ is influenced by other variables, so it is hoped that further researchers will conduct research related to the same theme, namely quality management with different indicators, in order to reveal 29.8. \% other variables that affect teacher pedagogical competence.
\end{abstract}

Keywords: Quality Management, Teacher Pedagogic Competence

\begin{abstract}
Abstrak
Tujuan dari penelitian ini adalah 1). untuk mengetahui manajemen mutu yang ada di SMP Unggulan Mukhtar Syafa'at Blokagung Banyuwangi, 2). untuk mengetahui kompetensi pedagogik guruyang ada di SMP Unggulan Mukhtar Syafa'at Blokagung Banyuwangi, 3). untuk mengetahui pengaruh manajemen mutu terhadap kompetensi pedagogik guruyang ada di SMP Unggulan Mukhtar Syafa'at Blokagung Banyuwangi. Penelitian ini menggunakan metode deskriptif kuantitatif dengan teknik product moment pada uji validitas data dan untuk mencari reliabilitas dat menggunakan rumus alpha, sedangkan pada uji hipotesis menggunakan uji $F$ dan uji $T$ kemudian untuk teknik analisis data menggunakan uji normalitas dengan menggunakan model regresi. Berdasarkan hasil penelitian yang sudah dilakukan bahwasanya manajemen mutu yang di kelola lembaga sudah bisa dikatakan baik. Kompetensi pedagogik Guru di SMP Unggulan Mukhtar Syafaat sudah tergolong baik dengan prosentasi nilai $61 \%$ - 80\% itu artinya kompetensi pedagogik guru sudah baik. Kemudian manajemen mutu sangat bepengaruh terhadap kompetensi pedagogik guru yakni sebesar 70,2\% dan 29,8\% dipengaruhi oleh variabel lain maka diharapkan bagi peneliti selanjutnya untuk melakukan penelitian terkait tema yang sama yakni manajemen mutu
\end{abstract}

Pengaruh Manajemen Mutu terhadap Kompetensi Pedagogik Guru di SMP Unggulan Mukhtar Syafa'at Blokagung Tegalsari Banyuwangi

Mahbub, Bambang Sugiarto 
dengan indikator yang berbeda, agar dapat mengungkap 29,8\% variabel lain yang mempengaruhi kompetensi pedagogik guru.

\section{Kata Kunci: Manajemen Mutu, Kompetensi Pedagogik Guru}

\section{A. Pendahuluan}

\section{Latar Belakang Masalah}

Kehadiran manajemen dalam lembaga pendidikan adalah untuk mengatur setiap kegiatan-kegiatan yang ada dalam lembaga tersebut agar tujuan yang dicapai dapat berjalan dengan efektif dan efesien. Manajemen adalah bagian terpenting dalam suatu lembaga untuk mencapai tujuan yang telah ditentukan dan lembaga yang baik adalah lembaga yang memiliki konsep manajemen sesuai dengan objek serta tempat organisasinya.

Pada umumnya manajemen merupakan suatu proses untuk mengatur proses berjalannya suatu lembaga dan penentuan tujuan atau sasaran yang akan dicapai dengan menetapakan jalan dan sumber yang akan digunakan untuk mencapai tujuan yang efektif dan efesien. Demikian pula dalam halnya yang berkaitan dengan lembaga pendidikan. Respon sekolah dalam upaya memperbaiki kinerja tenaga pendidik atau guru yang ada dalam lembaga tersebut, khususnya dalam penerapan dan pelaksanaan manajemen suatu organisasi kependidikan yang tentunya sangat berpengaruh penting dalam kesuksesan lembaga pendidikan.Peran seorang guru sangatlah penting sebagai pelaksana dalam kegiatan pembelajaran guru juga harus menanamkan jiwa kemandirian, keimana, ketaqwaan, dan membiasakan peserta didik berakhlakul karimah.

Keberhasilan sekolah sangatlah besar terutama dalam mendidik peserta didik kearah yang dicita-citakan. Hal ini selaras dalam pembukaan UUD 1945, yaitu mencerdaskan kehidupan bangsa. Dalam peningkatan mutu profesionalitas guru, kepala sekolah yang sangat berperan untuk mewujudkan pendidikan yang berkualitas. Karena dalam sebuah lembaga pendidikan peran seorang guru yang paling penting. Maka dari itu seharusnya para guru harus mendapatkan perhatian utama dari kepala sekolah selaku pemimpin yang paling berkuasa dalam suatu lembaga pendidikan. Perhatian tersebut berupa proses koordinasi, pengarahan, 
pendampingan, pembinaan, pengawasan, pengevaluasian, memotivasi, serta apresiasi, dan penghargaan yang diberikan oleh kepalah sekolah terhadap guru, agar guru terus menerus terpacu untuk meningkatkan profesionalitasnya.

\section{Rumusan Masalah}

Berdasarkan uraian yang telah dijelaskan diatas, maka peneliti dapat merumuskan masalah pada penelitian ini sebagai berikut:

a. Bagaimana manajemen mutu yang ada di SMP Unggulan Mukhtar Syafa'at Blokagung Banyuwangi?

b. Bagaimana kompetensi pedagogoik guru yang ada di SMP Unggulan Mukhtar Syafa'at Blokagung Banyuwangi?

c. Adakah pengaruh manajemen mutu terhadap kompetensi pedagogik guru yang ada di SMP Unggulan Mukhtar Syafa'at Blokagung Banyuwangi?

\section{Tujuan Penelitian}

a. Untuk mengetahui manajemen mutu yang ada di SMP Unggulan Mukhtar Syafa'at Blokagung Banyuwangi

b. Untuk mengetahui kompetensi pedagogik guruyang ada di SMP Unggulan Mukhtar Syafa'at Blokagung Banyuwangi

c. Untuk mengetahui pengaruh manajemen mutu terhadap kompetensi pedagogik guruyang ada di SMP Unggulan Mukhtar Syafa'at Blokagung Banyuwangi

\section{B. Tinjauan Pustaka}

\section{Manajemen Mutu}

Transformasi sekolah era kontemporer menuju sekolah bermutu terpadu di awali dari bentuk komitmen bersama terhadap mutu pendidikan yakni oleh komite sekolah, administratror, guru, staf, siswa, dan orang tua. Pengembangan manajemen mutu dalam pendidikan sesungguhnya mengadopsi dari berbagai konsep, tapi yang lebih dominan adalah dari konsep manajemen mutu dalam bidang industri. Akhirnya pengembangan mutu mengarah pada ranah pendidikan dan menjadi susatu konsep 
paten, sehingga mutu pendidikan menjelma menjadi kebutuhan primer bagi sekolah untuk bersaing dengan sekolah-sekolah yang lain.

Menurut Terry dan Rue (2008:1) "manajemen adalah suatu proses atau kerangka kerja, yang melibatkan bimbingan atau pengarahan suatu kelompok orangorang kearah tujuan-tujuan organisasional atau maksud-maksud yang nyata". Sedangkan menurut Juran dalam Nasution (2000: 15) kualitas atau mutu diartikan sebagai kecocokan penggunaan produk untuk memenuhi kebutuhan dan kepuasan pelanggan atau kesesuaian terhadap spesifikasi.

Menurut Edward Sallis dalam Arbangi, Dakir dan Umiarso (2016: 81) manajemen mutu terpadu atau TQM dalam konteks pendidikan merupakan sebuah filosofi metodologi tentang perbaikan terus menerus yang dapat dapat memberikan seperangkat alat praktis kepada setiap industri pendidikan dalam memenuhi kebutuhan, keinginan, dan harapan pelanggan, saat ini maupun masa yang akan datang. Atau juga bisa diartikan sebagai pendekatan yang sistematis, praktis, dan strategis dalam menyelengarakan suatu organisasi yang mengutamakan kepentingan pelanggan. Jadi dapat disimpulkan bahwasanya manajemen mutu adalah manajemen fungsional dengan pendekatan terus menerus yang difokuskan pada kualitas masyarakat yang sesuai dengan kebutuhan pelanggan.

\section{Karakteristik Manajemen Mutu}

Perlu diketahui dalam manajemen mutu ada beberapa karakteristik yang perlu diketahui yakni:

1) Fokus pada pelanggan, baik pelanggan internal maupun eksternal

2) Memiliki obsesi yang tinggi terhadap kualitas

3) Menggunakan pendekatan ilmiah dalam pengambilan keputusan dan pemecahan masalah

4) Memeiliki komitmen jangka panjang

5) Membutuhkan kerjasama tim

6) Memperbaiki proses secara kesinambungan

7) Menyelenggarakan pendidikan dan pelatihan

Pengaruh Manajemen Mutu terhadap Kompetensi Pedagogik Guru di SMP Unggulan Mukhtar Syafa'at Blokagung Tegalsari Banyuwangi

Mahbub, Bambang Sugiarto 
8) Memberikan kebebasan yang terkendali

9) Memiliki kesatuan yang terkendali

10) Adanya keterlibatan dan pemberdayaan karyawan

\section{Kompetensi Pedagogik Guru}

Kompetensi adalah sebuah kewenangan atau kekuasaan untuk menentukan atau memutuskan sesuatu hal dengan kata lain bahwa kompetensi disebut sebagai wewenang atau kewenangan. Sedangkan profesional menurut Wirawan (2002: 9) dalam Hasan Basri adalah pekerjaan yang dilaksanakan sesuai dengan persyaratan tertentu. Kata profesional juga bisa diartikan sebagai seseorang yang bekerja sesuai dengan keahliannya dan menghasilkan produk yang memuaskan sesuai dengan apa yang diharapkan atau sesuai dengan tujuan.

Johnson (dalam Sanjaya, 2010:277) berpendapat bahwa "Competency as rational performance which satisfactirily meets the objective for a desired condition, artinya kompetensi merupakan perilaku rasional guna mencapai tujuan yang dipersyaratkan sesuai dengan kondisi yang diharapkan”. Menurut Abdul Majid (dalam Fathurrohman dan Sutikno, 2007: 44) kompetensi adalah seperangakat tindakan inteligen penuh tanggung jawab yang harus dimiliki seseorang sebagai syarat untuk dianggap mampu melaksanakan tugas-tugas dalam bidang pekerjaan tertentu.

Sedangkan menurut Mulyasa (2003:37-38) merupakan perpaduan dari pengetahuan, keterampilan, nilai dan sikap yang direfleksikan dalam kebiasaan berpikir dan bertindak. Jadi kompetensi adalah kemampuan untuk melaksanakan tugas oleh seseorang dengan berdasarkan adanya pengetahuan, keterampilan, nilai dan sikap yang dimilikinya untuk mencapai tujuan pada tugas tersebut. Sadulloh (2011:2) mengutip pendapat Prof. Dr. J. Hoogveld yang menyatakan bahwa pedagogik adalah ilmu yang mempelajari masalah membimbing anak kearah tujuan tertentu yaitu supaya kelak ia mampu secara mandiri menyelesaikan tugas hidupnya.

Menurut Suprihatiningrum (2013: 101) Kompetensi pedagogik merupakan kemampuan yang berkaitan dengan pemahaman siswa dan pengelola pembelajaran yang mendidik dan dialogis. sedangkan yang dimaksud dengan kompetensi 
pedagogik dalam Permendiknas nomor 16 tahun 2007 tentang Standar Nasional Pendidik dan Tenaga Kependidikan (dalam Suprihatiningrum, 2013:101) ialah merupaka kemampuan guru dalam pengelolaan pembelajaran siswa. Lebih lanjut dalam penjelasan Peraturan Pemerintah Republik Indonesia nomor 19 tahun 2005, disebutkan bahwa yang dimaksud dengan kompetensi pedagogik adalah kemampuan mengelola pembelajaran peserta didik yang meliputi pemahaman terhadap peserta didik, perancangan dan pelaksanaan pembelajaran, evaluasi hasil belajar dan pengembangan peserta didik untuk mengaktualisasikan berbagai potensi yang dimilikinya.

\section{Indikator-Indikator Kompetensi Pedagogik Guru}

Beberapa indikator kompetensi pedagogik yang dimaksud dalam pasal 10 Undang-Undang nomor 14 tahun 2005 tentang Guru dan Dosen (Sanjaya, 2010:279) ialah:

(1) Pemahaman wawasan atau landasan kependidikan.

(2) Pemahaman terhadap peserta didik.

(3) Pengembangan kurikulum/silabus.

(4) Perancangan pembelajaran.

(5) Pelaksanaan pembelajaran yang mendidik dan dialogis.

(6) Pemanfaatan teknologi pembelajaran.

(7) Evaluasi hasil belajar.

(8) Pengembangan peserta didik untuk mengaktualisasikan berbagai potensi yang dimilikinya.

\section{Metode Penelitian}

\section{Jenis Penelitian}

Dalam penelitian ini suatu masalah yang akan diteliti terkait dengan pengaruh manajemen mutu terhadap kompetensi pedagogik guru di SMP Unggulan Mukhtar Syafa'at Blokagung Banyuwangi. Sesuai dengan judul yang peneliti ambil maka jenis penelitian yang digunakan adalah deskriptif dengan pendekatan kuantitatif yang bertujuan untuk mengetahui pengaruh antara variabel yakni pengaruh manajemen mutu 
terhadap kompetensi pedagogik guru di SMP Unggulan Mukhtar Syafa'at Blokagung Banyuwangi dengan cara melakukan pengolahan data atau teknik analisis data yang berbentuk angka.

Menurut Arikunto (2006: 5), "metode penelitian kuantitatif adalah suatu pendekatan penelitian yang secara primer yang menggunakan paradigma positif dalam pengembangan ilmu pengetahuan seperti: pemikiran tentang sebab akibat, reduksi kepada variabel, hipotesis dan pertanyaan spifik, menggunakan pengukuran dan observasi, serta pengujian teori menggunakan starategi penelitian seperti ekspirimen dan survei yang memberikan data statistik".

\section{Langkah-Langkah Penelitian Kuantitatif}

a. Tahap Konseptual (merumuskan dan membatsi masalah, meninjau kepustakaan yang relevan, mendefinisikan kerangka teoritis, merumuskan hipotesis). Tahap ini termasuk merenungkan, berpikir, membaca, membuat konsep, revisi konsep, teoritisasi, bertukar pendapat, konsulatsi dengan pembimbing, dan penelusuran pustaka, mengekplotasi perumusan dan penentuan masalah yang akan diteliti. Penelitian ini dimulai dengan kegiatan menjajaki permasalahan yang menjadi pusat perhatian peneliti dan kemudian peneliti mendefinisikan serta menformulasikan masalah penelitian tersebut dengan jelas sehingga mudah dimengerti.

b. Fase perancangan dan perencenaan (memilih rancangan penelitian, mengidentifikasi populasi yang diteliti, mengkhususkan metode untuk mengukur variabel penelitian, merancang rencana sampling, mengakhiri dan meninjau rencana penelitian, melaksanakan pilot penelitian dan parameter penelitian dan membuat revisi). Setelah masalah penelitian diformulasikan maka peneliti mendesain rancangan penelitian, baik desain model maupun penentuan parameter penelitian yang akan menuntun pelaksanaan penelitian mulai awal sampai akhir penelitian.

c. Mendesain instrumen pengumpulan data penelitian.

Agar dapat melakukan pengumpulan data penelitian yang sesuai dengan tujuan penelitian, maka desain instrumen pengumpulan data menjadi alat perekam data yang sangat penting di lapangan. 
d. Fase analitik (analisi data, penafsiran hasil) mengolah dan menganalisis data hasil penelitian.

Data yang dikumpulkan dari lapangan diolah dan di analisis untuk menemukan kesimpulan-kesimpulan yang diantaranya kesimpulan dari hasil pengujian hipotesis penelitian.

e. Fase diseminasi mendesain laporan hasil penelitian.

Pada tahap akhir, agar hasil penelitian dapat dibaca, dimengerti dan diketahui oleh masyarakat luas, maka hasil penelitian tersebut disusun dalam bentuk laporan hasil penelitian.

\section{Sumber Data}

Sumber data dalam penelitian adalah subjek dari mana diperoleh, apabila peneliti mengunakan kuesioner dalam pengukuran datanya maka sumber datanya dinamakan responden. Dalam penelitian ini respondennya adalah seluruh dewan guru yang ada di SMP Unggulan Mukhtar Syafa'at. Ada dua macam jenis sumber data yakni:

a. Data primer adalah data yang diperoleh peneliti dari sumber asli. Dalam penelitian data primer diperoleh melalui jawaban responden atas pertanyaan-pertanyaan dari kuesioner yang dibagikan kepada seluruh dewan guru yang ada di SMP Unggulan Mukhtar Syafa'at.

b. Data sekunder adalah data yang diperoleh dalam bentuk jadi, sudah dikumpulkan dan diolah oleh pihak lain biasanya sudah dalam bentuk publikasi. Dalam penelitian ini data sekunder yang diperoleh melalui data lembaga, struktur lembaga dan lain-lain.

\section{Instrumen Penelitian}

Menurut Arikunto (2014:101) instrumen penelitian bisa diartikan sebagai alat bantu merupakan saran yang dapat diwujudkan dalam benda, misalnya angket (questioner), daftar yang cocok (checklist), atau pedoman wawancara (interview guide atauinterview schedule), lembar pengamatan atau panduan pengamatan (observation sheet atau observation schedule), soal tes yang terkadang hanya disebut tes saja, inventori (inventory), skala (scale), dan lain sebagainya. Dalam penelitian ini menggunakan instrumen penelitian berupa angket (questioner) yang mana angket 
tersebut dibagikan kepada responden dalam bentuk pernyataan dan nantinya akan diambil datanya kemudian dilakukan analisis data.

Tabel 3.1

Kisi-Kisi Instrument Penelitian

\begin{tabular}{|c|c|c|c|}
\hline Variabel & Sub Variabel & Indikator-Indikator & No. Item \\
\hline \multirow[t]{2}{*}{$\begin{array}{l}\text { Manajemen Mutu } \\
\text { (Variabel X) }\end{array}$} & $\begin{array}{l}\text { Pengertian } \\
\text { Manajemen Mutu }\end{array}$ & $\begin{array}{l}\text { 1. Manajemen adalah } \\
\text { suatu proses atau kerangka } \\
\text { kerja, yang melibatkan } \\
\text { bimbingan atau pengarahan } \\
\text { suatu kelompok orang-orang } \\
\text { kearah tujuan-tujuan } \\
\text { organisasional atau maksud- } \\
\text { maksud yang nyata. } \\
\text { Kualitas atau mutu diartikan } \\
\text { sebagai kecocokan } \\
\text { penggunaan produk untuk } \\
\text { memenuhi kebutuhan dan } \\
\text { kepuasan pelanggan atau } \\
\text { kesesuaian terhadap } \\
\text { spesifikasi. } \\
\text { Manajemen mutu terpadu } \\
\text { atau TQM dalam konteks } \\
\text { pendidikan merupakan sebuah } \\
\text { filosofi metodologi tentang } \\
\text { perbaikan terus menerus yang } \\
\text { dapat dapat memberikan } \\
\text { seperangkat alat praktis } \\
\text { kepada setiap industri } \\
\text { pendidikan dalam memenuhi } \\
\text { kebutuhan, keinginan, dan } \\
\text { man pelanggan, saat ini } \\
\text { masa yang akan } \\
\text { mang. }\end{array}$ & $1-3$ \\
\hline & $\begin{array}{l}\text { Prinsip-Prinsip } \\
\text { Manajemen Mutu }\end{array}$ & $\begin{array}{l}\text { 1. Fokus pada pelanggan } \\
\text { 2. Kepemimpinan } \\
\text { 3. Pelibatan anggota }\end{array}$ & $1-8$ \\
\hline
\end{tabular}




\begin{tabular}{|c|c|c|c|}
\hline Variabel & Sub Variabel & Indikator-Indikator & No. Item \\
\hline & & $\begin{array}{l}\text { 4. Pendekatan proses } \\
\text { 5. Pendekatan sistem pada } \\
\text { manajemen } \\
\text { 6. Perbaikan berkesinambungan } \\
\text { 7. Pendekatan fakta pada } \\
\text { pengambilan keputusan } \\
\text { 8. Hubungan yang saling } \\
\text { menguntungkan dengan } \\
\text { pemasok }\end{array}$ & \\
\hline & $\begin{array}{l}\text { Karakteristik } \\
\text { Manajemen Mutu }\end{array}$ & $\begin{array}{l}\text { 1.Fokus pada pelanggan, baik } \\
\text { pelanggan internal maupun } \\
\text { eksternal } \\
\text { 2. Memiliki obsesi yang tinggi } \\
\text { terhadap kualitas } \\
\text { 3. Menggunakan pendekatan } \\
\text { ilmiah dalam pengambilan } \\
\text { keputusan dan pemecahan } \\
\text { masalah } \\
\text { 4. Memeiliki komitmen jangka } \\
\text { panjang } \\
\text { 5. Membutuhkan kerjasama tim } \\
\text { 6. Memperbaiki proses secara } \\
\text { kesinambungan } \\
\text { 7. Menyelenggarakan pendidikan } \\
\text { dan pelatihan } \\
\text { 8. Memberikan kebebasan yang } \\
\text { terkendali } \\
\text { 9. Memiliki kesatuan yang } \\
\text { terkendali } \\
\text { 10. Adanya keterlibatan dan } \\
\text { pemberdayaan karyawan }\end{array}$ & $1-10$ \\
\hline & $\begin{array}{l}\text { Implementasi } \\
\text { Manajemen } \\
\text { Mutu }\end{array}$ & $\begin{array}{l}\text { 1. Produktivitas Internal } \\
\text { Yaitu berupa hasil yang dapat } \\
\text { diukur secara kuantitatif, }\end{array}$ & $1-2$ \\
\hline
\end{tabular}

Pengaruh Manajemen Mutu terhadap Kompetensi Pedagogik Guru di SMP Unggulan Mukhtar Syafa'at Blokagung Tegalsari Banyuwangi

Mahbub, Bambang Sugiarto 


\begin{tabular}{|c|c|c|c|}
\hline Variabel & Sub Variabel & Indikator-Indikator & No. Item \\
\hline & & $\begin{array}{l}\text { seperti jumlah atau prosentase } \\
\text { lulusan sekolah, atau jumlah } \\
\text { Gedung dan lokal yang } \\
\text { dibangun sesuai dengan } \\
\text { persyaratan yang telah } \\
\text { ditetapkan } \\
\text { 2. Produktivitas Eksternal } \\
\text { Yaitu berupa hasil yang tidak } \\
\text { dapat diukur secara kuantitatif, } \\
\text { karena bersifat kualitatif yang } \\
\text { hanya dapat diketahui setelah } \\
\text { melewati tenggang waktu } \\
\text { tertentu yang cukup lama. }\end{array}$ & \\
\hline $\begin{array}{l}\text { Kompetensi } \\
\text { Profesional Guru } \\
\text { (Variabel Y) }\end{array}$ & $\begin{array}{l}\text { Pengertian } \\
\text { Kompetensi } \\
\text { Pedagogik Guru }\end{array}$ & $\begin{array}{l}\text { 1. Kompetensi adalah sebuah } \\
\text { kewenangan atau kekuasaan } \\
\text { untuk menentukan atau } \\
\text { memutuskan sesuatu hal dengan } \\
\text { kata lain bahwa kompetensi } \\
\text { disebut sebagai wewenang atau } \\
\text { kewenangan } \\
\text { 2. Kata pedagogik juga bisa } \\
\text { diartikan sebagai seseorang } \\
\text { yang bekerja sesuai dengan } \\
\text { keahliannya dan menghasilkan } \\
\text { produk yang memuaskan sesuai } \\
\text { dengan apa yang diharapkan } \\
\text { atau sesuai dengan tujuan } \\
\text { 3. Kompetensi pedagogik guru } \\
\text { adalah kemampuan, kecakapan, } \\
\text { dan pemenuhan persyaratan } \\
\text { yang dimilki guru sebagai } \\
\text { pendidik untuk diterapkan dan } \\
\text { dilaksanakan dalam proses } \\
\text { pembelajaran sesuai dengan } \\
\text { mata kuliah yang ditekuninya }\end{array}$ & $1-3$ \\
\hline
\end{tabular}




\begin{tabular}{|c|c|c|c|}
\hline Variabel & Sub Variabel & Indikator-Indikator & No. Item \\
\hline & $\begin{array}{l}\text { Komponen } \\
\text { Kompetensi } \\
\text { Pedagogik Guru }\end{array}$ & $\begin{array}{l}\text { 1. Kemampuan mengenal peserta } \\
\text { didik secara mendalam } \\
\text { 2. Kemampuan menguasai bidang } \\
\text { studi } \\
\text { 3. Kemampuan } \\
\text { menyelenggarakan } \\
\text { pembelajaran yang mendidik } \\
\text { 4. Kemampuan mengembangkan } \\
\text { kompetensi profesional secara } \\
\text { berkelanjutan } \\
\text { 5. Menguasai landasan } \\
\text { pendidikan } \\
\text { 6. Menyusun program pengajaran } \\
\text { 7. Menilai hasil dan proses } \\
\text { pembelajaran yang telah } \\
\text { dilaksanakan. }\end{array}$ & $1-7$ \\
\hline
\end{tabular}

Sumber Data: Hasil Olahan Peneliti

\section{Uji Validitas dan Reabilitas}

\section{Uji Validitas}

Untuk menguji kuisioner penelitian, menggunakan uji validitas butir instrumen, dikatakan memiliki validitas apabila mempunyai dukungan besar terhadap skor total, untuk mengukur validatas butir kuisioner dengan menggunakan rumus korelasi product moment dengan rumus:

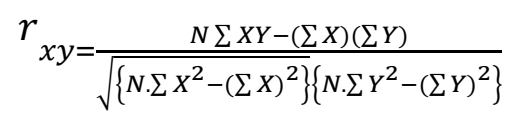

Keterangan:

$$
\begin{array}{ll}
r_{x y} & =\text { koefisien korelasi } \mathrm{x} \text { dan } \mathrm{y} \\
\mathrm{N} & =\text { Jumlah sampel/populasi } \\
\sum X Y & =\text { Jumlah hasil perkalian antar sekor } \mathrm{x} \text { dan } \mathrm{y} \\
\sum X & =\text { Jumlah sekor } \mathrm{x} \\
\sum y & =\text { Jumlah sekor } \mathrm{y}
\end{array}
$$

Pengaruh Manajemen Mutu terhadap Kompetensi Pedagogik Guru di SMP Unggulan Mukhtar Syafa'at Blokagung Tegalsari Banyuwangi

Mahbub, Bambang Sugiarto 
Tabel: 3.2

Interpretasi Nilai $\mathbf{r}$

\begin{tabular}{|l|l|}
\hline Besarnya nilai $r$ & Interpretasi \\
\hline Antara 0,800 sampai dengan 1,00 & Sangat tinggi \\
\hline Antara 0,600 sampai dengan 0,800 & Tinggi \\
\hline Antara 0,400 sampai dengan 0,600 & Sedang \\
\hline Antara 0.200 sampai dengan 0,400 & Rendah \\
\hline Antara 0,00 sampai dengan 0,200 & Sangat rendah \\
\hline
\end{tabular}

Sumber Data: Hasil Olahan Peneliti

2. Reabilitas

Menurut Sugiyono (2017: 135) mendefinisikan bahwa, "menguji reliabilitas dilakukan dengan internal consistency dengan teknik belah dua yang dianalisis dengan rumus alpha. Yaitu:

$$
\left.r_{11=\left\{\frac{k}{k-2}\right\}}\right\}\left\{\frac{\sum \sigma b 2}{\sigma_{\bar{t}}^{2}}\right\}
$$

Dengan keterangan:

$\mathrm{r} 1=$ reliabilitas instrumen

$\mathrm{k} \quad=$ banyaknya butir pertanyaan atau banyaknya soal

$\sum \sigma b 2=$ jumlah varian butir

$2 \sigma t=$ viaran total

\section{Teknik Pengumpulan Data}

Untuk memperoleh data suatu informasi dan keterangan-keterangan lain yang diperlukan, maka penelitian ini menggunakan teknik pengumpulan data primer. Pengumpulan data primer adalah Teknik pengumpulan data yang dilakukan secara Pengaruh Manajemen Mutu terhadap Kompetensi Pedagogik Guru di SMP Unggulan Mukhtar Syafa'at Blokagung Tegalsari Banyuwangi Mahbub, Bambang Sugiarto 
langsung pada lokasi penelitian yakni dengan memberikan kuesioner kepada rsponden. Teknik ini dimaksud adalah metode pengumpulan data dengan cara memberikan seperangkat pertanyaan tertulis kepada responden untuk dijawab. Kemudian jawabanjawaban responden ini di beri nilai atau skor menggunakan skala Likert. Melihat dari segi teknik pengumpulan data maka teknik pengumpulan data yang digunakan dalam penelitian ini adalah sebagai berikut:

1. Angket

Menurut Sugiyono (2018: 219), teknik angket merupakan teknik pengumpulam data yang dilaksanakan sengan cara memberikan sperangkat pernyataan atau pertanyaan tertulis kepada responden untuk dijawab. Teknik angket ini merupakan teknik yang efesien karena dapat mengukur data secara jelas dan mampu menjawab apa yang diharapkan dari responden.

2. Observasi

Menurut Suryani dan Hendryadi (2016: 181), “observasi merupakan salah satu teknik pengumpulan data yang tidak hanya mengukur dari sikap responden (melalui angket) tetapi juga dapat digunakan merekam fenomena dan situasi yang terjadi”.

\section{Dokumentasi}

Menurut Sugiyono (2015: 245) dokumentasi merupakan catatan dalam sebuah peristiwa yang berbentuk tulisan, gambar atau karya monumental lainya (Sugiyono, 2015: 245). Dokumentasi digunakan unruk mendapatkan data berupa sejarah sekolah, struktur, program-program sekolah, gambar-gambar kegiatan dan dokumen lainya yang berhubungan dengan variabel penelitian. Dari dokumentasi yang didapat penulis hanya mengambil sejarah sekolah saja, karena menurut penulis sejarah sekolah lebih penting dari pada yang lain.

\section{Teknik Analisis Data}

1. Uji Normalitas

Uji normalitas ini bertujuan untuk menguji apakah regresi, variabel penggagu atau residual memiliki distribusi normal. Modal regresi yang baik adalah memiliki distribusi data normal atau mendekati normal. Pengujian normalitas dapat dilihat dari 
hasil uji Kolmogorov Smirrnov. Apabila nilai $\mathrm{p}$ value > 0,05 dapat disimpulkan bahwa data berdistribusi normal.

\section{Uji Regresi Linier Sederhana}

Menurut Abdul Muhid (2012: 118-119) Harga b merupakan fungsi koefisien korelasi. Bila koefisien korelasi tinggi, maka B juga besar, sebaliknya bila koefisien korelasi rendah maka harga B juga rendah (kecil). Selain itu bila koefisien negatif, maka harga B juga negatif, sebaliknya bila koefisien korelasi positif maka harga B juga positif. Selain itu juga untuk mencari nilai a dan $b$ dapat dicari dengan rumus:

$$
\begin{aligned}
& \mathrm{a}=\frac{n \sum X i Y i-\left(\sum X i\right)\left(\sum y i\right)}{n \sum X i^{2-\left(\sum X i\right)^{2}}} \\
& \mathrm{~b}=\frac{n \sum X i Y i-\left(\sum X i\right)\left(\sum y i\right)}{n \sum X i^{2-\left(\sum X i\right)^{2}}}
\end{aligned}
$$

\section{a. Analisis Deskriptif Prosentase}

Analisis dalam penelitian ini digunakan untuk mengetahui dan menggambarkan mengenai keadaan variabel. Baik itu variabel pengaruh manajemen mutu dan kompetensi pedagogik guru di SMP Unggulan Mukhtar Syafa'at Blokagung Tegalsari Banyuwangi. Penggambaran dua variabel ini dinyatakan dalam bentuk prosentase dan selanjutnya ditafsirkan dengan tabel kriteria yang telah dibuat. Adapun langkah analisis deskriftif prosentase adalah:

1) Memberikan sekor terhadap jawaban responden dengan ketentuan:

a) Nilai 5 untuk siswa yang menjawab sangat setujuh (SS)

b) Nilai 4 untuk siswa yang menjawab setujuh (S)

c) Nilai 3 untuk siswa yang menjawab netral $(\mathrm{N})$

d) Nilai 2 untuk siswa yang menjawab tidak setujuh (TS)

e) Nilai 1 untuk siswa yang menjawab sangat tidak setujuh (STS)

2) Memasukan hasil kedalam rumus:

$$
\%=\frac{n}{N} x 100 \%
$$




\section{Dimana :}

$\%=$ Tingkat prosentasi yang berhasil dicapai

$\mathrm{n}=$ Nilai yang diperoleh

$\mathrm{N}=$ Nilai total

Tabel 3.3

Indeks Konfirmasi Nilai Angket

\begin{tabular}{|c|c|c|}
\hline No & Angka & Kategori \\
\hline 1 & $81 \%$ sampai dengan $100 \%$ & Sangat baik \\
\hline 2 & $61 \%$ sampai dengan $80 \%$ & Kuat \\
\hline 3 & $41 \%$ sampai dengan $60 \%$ & Cukup kuat \\
\hline 4 & $21 \%$ sampai dengan $40 \%$ & Lemah \\
\hline 5 & $0 \%$ sampai dengan $20 \%$ & Sangat lemah \\
\hline
\end{tabular}

Sumber Data: Sugiyono (2015: 185)

b. Pengujian Hipotesis Penelitian

1) Pengaruh $X$ terhadap $Y$ secara stimultan ( uji $T$ )

a) Merumuskan hipotesis statistik

1. Ho : $\beta_{1}=\beta_{2}=0$, artinya $\mathrm{X}$ secara simultan tidak berpengaruh signifikasi terhadap Y.

2. Ha : $\beta_{1}=\beta_{2} \neq 0$, artinya $\mathrm{X}$ secara simultan berpengaruh signifikan terhadap $\mathrm{Y}$.

b) Kaidah pengambilan keputusan

Pengambilan keputusan dengan taraf signifikan 5\% sebagaiberikut :

1. Sig $<0,05 \longrightarrow$ Ho ditolak maka Ha diterima

2. Sig $<0,05 \longrightarrow$ Ho diterima maka Ha ditolak

Untuk membantu pengolahan data secara cepat dan tepat, maka pengolahan datanya dilakukan melalui SPSS 22.

2) Pengaruh $X$ rerhadap $Y$ secara simultan ( Uji F)

a) Merumuskan hipotesis statistik

Pengaruh Manajemen Mutu terhadap Kompetensi Pedagogik Guru di SMP Unggulan Mukhtar Syafa 'at Blokagung Tegalsari Banyuwangi

Mahbub, Bambang Sugiarto 
1. Ho: $\beta_{1}=\beta_{2}=0$, artinya $\mathrm{X}$ secara simultan tidak berpengaruh signifikan terhadap Y.

2. Ha: $\beta_{1}=\beta_{2}=0$, artinya $\mathrm{X}$ secara simultan berpengaruh signifikan terhadap Y.

b) Kaidah pengambilan keputusan

Pengambilan keputusan dengan taraf signifikan 5\% sebagai berikut:

1. Sig $<0,05 \longrightarrow$ Ho ditolak maka Ha diterima

2. Sig $>0,05 \longrightarrow$ Ho diterima maka Ha ditolak

Untuk membantu pengolahan data secara cepat dan tepat, maka pengolahan datanya dilakukan melalui SPSS 22.

\section{Hasil Penelitian}

\section{Analisis Data}

\section{a. Variabel X}

Berdasarkan data tabel 4.7 tingkat prosentase variabel $\mathrm{X}$ yang berhasil dicapai adalah sebesar 78\%. Jika dilihat pada tabel indeks konfirmasi nilai angket, maka Nilai tersebut berada pada interval 61\% sampai dengan $80 \%$ dengan kategori baik. Hal tersebut juga dilihat dari berbagai indikator manajemen mutu yakni Fokus pada pelanggan baik pelanggan internal maupun eksternal 80\%, Memiliki obsesi yang tinggi terhadapkualitas $75 \%$, Menggunakan pendekatan ilmiah dalam pengambilan keputusan dan pemecahan masalah 70\%, Memiliki komitmen jangka panjang 66\%, Membutuhkan kerjasama tim 78\%, Memperbaiki proses secara kesinambungan $72 \%$, Menyelenggarakan pendidikan dan pelatihan 78\%, Memberikan kebebasan yang terkendali 77\%, Memiliki kesatuan yang terkendali $74 \%$ Adanya keterlibatan dan pemberdayaan karyawan 60\%. Dengan demikian menunjukkan bahwa manajemn mutu SMP Unggulan Mukhtar Syafa'at Blokagung Tegalsari Banyuwangi tergolong baik.

\section{b. Variabel Y}

Sesuai dengan apa yang diuraikan pada bagian sebelumnya bahwa permasalahan kedua yang dipertanyakan dalam penelitian ini adalah bagaimana kompetensi pedagogik guru yang ada SMP Unggulan Mukhtar Syafa'at Blokagung 
Tegalsari Banyuwangi, Hasil penelitian ini menunjukkan bahwa tingkat prosentase variabel Y yang berhasil dicapai adalah sebagai berikut:

$$
\begin{aligned}
\% & =\frac{n}{N} \times 100 \% \\
= & \frac{1147}{1500} \times 100 \% \\
= & 76 \%
\end{aligned}
$$

\section{Uji Hipotesisi}

Analisis regresi memerlukan pengujian yang sesuai untuk memastikan keeratan hubungan dari variabel-variabel yang digunakan. Pengujian tersebut meliputi uji T dan F.

\section{1) Uji T}

Uji T digunakan untuk mengetahui apakah pengaruh variabel fungsi manajemen (X) dan variabel mutu tenaga pendidik (Y) signifikan atau tidak. Kesimpulan dari uji T diperoleh setelah membandingkan $t$ hitung dan $t$ tabeldengan taraf signifikansi 0,05 atau 5\%. Kriteria pengambilan keputusannya adalah:

a) Apabila t hitung > t tabel, maka Ho ditolak dan Ha diterima, yang artinya variabel bebas secara parsial memiliki pengaruh nyata dan signifikan terhadap variabel terikat.

b) Apabila t hitung < t tabel, maka Ho diterima dan Ha ditolak, yang artinya variabel bebas secara parsial tidak memiliki pengaruh nyata dan tidak signifikan terhadap variabel terikat.

\section{E. Kesimpulan}

1. Berdasarkan hasil penelitian yang sudah dilakukan bahwasanya manajemen mutu yang di kelola lembaga sudah bisa dikatakan baik. Untuk pihak yang terkait diharapkan untuk lebih baik lagi dalam mengelola manajemen mutu agar kompetensi pedagogik guru lebih meningkat lagi di tahun berikutnya.

2. Berdasarkan hasil penelitian yang telah dilakukan bahwasanya kompetensi pedagogik Guru di SMP Unggulan Mukhtar Syafaat Blokagung Banyuwangi sudah tergolong 
baik dengan prosentasi nilai $61 \%$ - $80 \%$ itu artinya kompetensi pedagogik guru sudah baik.

3. Berkaitan dengan hasil penelitian manajemen mutu sangat bepengaruh terhadap kompetensi pedagogik guru yakni sebesar $70,2 \%$ dan $29,8 \%$ dipengaruhi oleh variabel lain maka diharapkan bagi peneliti selanjutnya untuk melakukan penelitian terkait tema yang sama yakni manajemen mutu dengan indikator yang berbeda, agar dapat mengungkap 29,8\% variabel lain yang mempengaruhi kompetensi pedagogik guru.

\section{F. Daftar Pustaka}

2006. Prosedur Penelitian Suatu Pendekatan Praktik. Jakarta: Rineka Cipta.

2000. Manajemen Mutu Terpadu: Total Quality Management. Jakarta: Ghalia Indonesia.

2016. Metode Riset Kuatitatif Teori dan Aplikasi Pada Penelitian Bidang Mnajemen dan Ekonomi Islam. Jakarta: Kencana.

Arbangi, Dakir dan Umiarso. 2016. Manajemen Mutu Pendidikan. Jakarta: Kencana.

Arikunto, Suharsimi. 2014. Prosedur Penelitian. Jakarta: Renika Cipta.

Basri, Hasan. 2015. Kepemimpinan Pendidikan. Bandung: CV Pustaka Setia.

Erma Purna Dewi, Ni Wayan. 2017. Meningkatkan Kualitas Guru Untuk Pendidikan Yang Lebih Baik. (Online), Vol.,1, No, 8, (https://www.researchgate.net/poblication/315099931, diakses 16 Maret 2017).

Nasution, M. Nur. 2015. Manajemen Mutu Terpadu: Total Quality Management. Jakarta: Ghalia Indonesia.

Nawawi, Handari. 2000. Manajemen Sumber Daya Manusia Untuk Bisnis Yang Kompetitif. Yokyakarta: Gajah Mada University Pres 
Saefullah. 2014. Manajemen Pendidikan Islam.Bandung: Pustaka setia

Sallis, Edward. 2006. Total Quality Management in Education (manajemen Mutu pendidikan). Yogyakarta: IRCISoD

Sugiyono. 2017. Metode Penelitian Kuantitaif, Kualitatif, dan R\&D. Bandung: Alfabeta, Suryani dan Hendryadi. 2015. Metode Riset Kuatitatif Teori dan Aplikasi Pada Penelitian Bidang Mnajemen dan Ekonomi Islam. Jakarta: Premadamedia Group.

Terry, George R \& Rue, Leslie W. 2008. Dasar-dasar Manajemen. Jakarta: PT Bumi Aksara.

Usman, Husaini. 2006. Manajemen Teori, Praktek dan Riset Pendidik. Jakarta: PT Bumi Aksara 